художественное текстообразование XIX века отличается конструированием и форматированием онирической повествовательной реальности, которая характеризируется множественностью, метафоричностью, фантастичностью и эмоционально-смысловой значимостью повествовательного изображения. С точки зрения лингвосемиотики исключительной особенностью французского художественного нарратива XIX века есть “измененные состояния сознания" писателя, выступающие референтами отображения и конструирования онирической повествовательной реальности. В статье определено, что французский онирический нарратив сконструирован в дискурсе снов и сонных визий гомодиегетического повествователя, который соотносится с языковой личностью самого французского писателя. Установлено, что в анализируемом романе “Aurélia ou le rêve et la vie” текстуальными средствами создания квазиреальности выступают онирические лексемы, а также многочисленные средства образно-стилистической фигуративности с семой 'мнимое / невозможное'.

Ключевые слова: онирический нарратив, онирическая повествовательная реальность, лингвосемиотика, французское художественное текстообразование, измененные состояния сознания.

Savchuk Ruslana. The French onieric Narrative Through Semiotic Analysis (on the Example of "Aurélia ou le rêve et la vie" by Gérard de Nerval). The present research paper has outlined and has analyzed the most revealing linguistic narrative and cognitive mechanisms of the oneiric narrative formatting, found in the $19^{\text {th }}$ century French fictional text formation. Exploring the text-forming potential of the "altered states of consciousness" as sign-language structures reflecting the narrative strategies in French prose works has allowed us to trace the dynamics of the writers' narrative thinking as the representatives of a particular historical and cultural era. The $19^{\text {th }}$ century French fictional texts are those examples of the writers' artistic thinking that reflect human beliefs, thoughts and feelings of each historical period and consequently, it analysis is necessary to reconstruct the mechanisms of the transformation of cognitive structures into sign language forms. For the purpose of determining the most noticeable trends in the oneiric narrative formation and formatting, the main regularities of generating and unfolding the narrative through stylistic figurativeness in terms of the semiosis of narrative techniques, techniques or tactics of the French fictional text formation have been clarified. From the standpoints of linguistics, semiotics, as well as the acquisition of semantics of possible worlds and stylistics, it has been singled out that the $19^{\text {th }}$ century French fictional text formation is distinguished by the construction and formatting of onieric narrative reality, characterized by the multiplicity of images. From the point of view of semiotic approach, the notable feature of the $19^{\text {th }}$ century French fictional text formation are the writer "altered states of consciousness", who act as referents of the reflection and construction of onieric narrative reality. The paper also has revealed that the French onieric narrative is constructed in the homodiegetic narrator discourse of dreams and dreamy visions that is related to the linguistic personality of the French writer himself. It has been established that in the novel "Aurélia ou le rêve et la vie", the textual means of creating the quasi-reality are onieric lexical units and numerous means of stylistic figurativeness with the seme of 'imaginary / impossible'.

Key words: onieric narrative, onierici narrative reality, semiotics, French fictional text formation, "altered states of consciousness".

DOI: https://doi.org/10.32782/2410-0927-2020-12-28

УДК 811.111 .142

Юрій Семенов, Ніна Дюканова

\title{
ЗАСТОСУВАННЯ ФРАЗОВИХ БАНКІВ В АНГЛІЙСЬКИХ АКАДЕМІЧНИХ ТЕКСТАХ
}

Стаття має на меті охарактеризувати таку інновацію, як «банк академічних фраз», а також можливості його застосування при написанні і/ або редагуванні англійської академічної прози. Йдеться, зокрема, про жанри наукової статті й дисертації. Концепція «банк академічних фраз» базується на підході до аналізу академічних текстів, запропонованому видатним британським лінгвістом Джоном Свейлсом (John Swales) у 1980 pp. Він виявив деякі риторичні звороти, а також «крок» як частину тексту, що виконує конкретну комунікативну функцію. Джон Свейлс прагнув показати специфіку, а також універсальний характер мови, яка при цьому використовується. «Крок» як одиниця риторичного аналізу вживається зараз як основна складова банку академічних фраз. Вважається, що сучасна академічна англійська мова містить значне фразеологічне нашарування. Банк академічних фраз складає загальний ресурс для науково-педагогічних працівників. Він спроможний надати їм фразеологічні компоненти, організовані за принципом головних розділів наукової статті або дисертації. Використання фразових банків допомагає авторам правильно організувати академічні роботи, вставляючи готові фрази туди, де це доцільно. У цій роботі предметом дослідження є стилістика та фразеологія науково-технічної прози відповідно до класичних розділів академічної роботи, а саме: Анотація, Вступ, Матеріали і Методи, Результати, Обговорення результатів роботи і Висновки. Викладено критерії добору фраз, придатних до застосування у фразових банках. Розглянуто питання плагіату при написанні академічних текстів. На конкретних прикладах проаналізовано особливості стилю науково-технічних документів, які знайшли своє відображення у фразових банках. Надано універсальні рекомендації щодо вживання

(С Семенов Ю., Дюканова Н., 2020 
банків академічних фраз незалежно від предметної галузі, жанру та обсягу роботи.

Ключові слова: фразовий банк, жанри наукової статті і дисертації, достовірність інформації, критичний аналіз літератури, обережність формулювань, безособовість.

Вступ. Усунення бар’єрів у доступі до різноманітної інформації при здійсненні наукової діяльності є об'єктивними факторами, які сприяють підвищенню рівня вищої освіти. До критеріїв якісної підготовки кадрів у цій галузі відносять написання і публікацію статей у фахових виданнях за кордоном. Це стає необхідним складником роботи магістрантів, аспірантів та науково-педагогічних працівників будь-якого вищого навчального закладу і часто становить для них неабияку проблему. Загальновідомо, що публікація наукових статей у високорейтингових рецензованих журналах $є$ складним завданням навіть для носіїв мови, і лише третина рукописів отримує більш-менш схвальні рецензії з необхідністю їх доопрацювання. Тому доцільним $\epsilon$ виявлення загальних вимог, а також стилістичних особливостей жанру науково-технічних документів та пошук їх універсалізації. У процесі дослідження літератури ми окреслили таку інновацію, як «Academic Phrasebank» (банк академічних фраз), про що йдеться в цій статті.

Отже, актуальність роботи визначають тим фактом, що вимога обов'язкової публікацій науково-педагогічними працівниками вищих навчальних закладів наукових статей у журналах, індексованих у Scopus, Web of Science або Core Collection, зумовлює необхідність точного дотримання стильових особливостей жанру, чому й сприяє використання банків готових фраз [1; $3 ; 4 ; 6]$. Це є так само важливим для амбіційних магістрантів і аспірантів, які прагнуть писати свої курсові і дипломні роботи, а згодом кандидатські і докторські дисертації англійською мовою.

Хоча питання стилістики та фразеології стилю науково-технічної прози перебували в площині студіювання багатьох вітчизняних та зарубіжних вчених [1-8], складання банків фраз можна вважати явищем відносно новим. Вперше дослідження, що призвели до появи цієї інновації, розпочав видатний британський вчений John M. Swales у 1980 pp. Ретельно проаналізувавши низку наукових статей та дисертацій, дослідник пов'язав кліше академічного письма з функціями академічної комунікації. Особливу увагу автор приділяв стилістичним особливостям оформлення класичних розділів наукової статті/ дисертації, а саме: Introduction (Вступ), Materials and Methods (Матеріали та методи), Results (Результати) та Discussion (Обговорення результатів дослідження), скорочено IMRAD, а також Abstract (Анотація) i Conclusions (Висновки). На підставі глибокого дослідження низки наукових робіт Swales дійшов висновку, що академічна проза $\epsilon$ фразеологічною за своєю природою, i що можна ідентифікувати певні «кроки», які ефективно виконують саме комунікативну функцію [7; 8].

У подальшому комп'ютерна технологія дозволила накопичувати великі фразові банки в різних галузях знань, що відкрило широкі перспективи для їхнього практичного застосування. Одне 3 нещодавніх досліджень було присвячено виявленню критеріїв відбору фраз, придатних для повторного застосування/ внесення до банку. Це було зроблено на підставі аналізу детальних анкет, репрезентованих 45 авторитетними вченими 3 двох британських вищих навчальних закладів. Прикметно, що висновок полягав у такому: фраза, придатна для внесення до банку, 1) не має унікальної або хоча б оригінальної конструкції; 2) не відображає точку зору того чи того конкретного автора; 3) $є$ лаконічною, тобто відповідає принципу економії, i до іiі складу входить не більше 10 лексем; 4) містить не більше чотирьох номінацій, пов'язаних із конкретною предметною галуззю[4].

Останнім часом укладання банків академічних фраз успішно проводить Манчестерський університет у Великій Британії. Ресурсом постачання фраз у [4] є 100 аутентичних текстів дипломних робіт і дисертацій із широкого спектра наукових дисциплін. Окремі речення 3 цих текстів підлягають спрощенню, компресії за рахунок сполучників, прийменників, слів-зв'язок тощо. Найчастіше з них вилучений контекст або його обмежують до мінімум чотирьох номінацій (див. вище). При цьому керуються прагматичними міркуваннями, а саме: чи виконує та чи та фраза певну комунікативну функцію і чи є повнозначні слова (іменники, дієслова, прикметники) універсальними (generic) за своєю природою. 
Отже, застосування банків фраз унеможливлює спробу звинуватити авторську роботу в плагіаті, а цьому аспекту рецензенти й наукова громада завжди приділяли пильну увагу[2].

Метою даної статті $\epsilon$ аналіз сучасної літератури і надання рекомендацій щодо вживання фразових висловів при написанні академічних робіт англійською мовою. Ці рекомендації $\epsilon$ прагматичними і мають загальний характер, тобто не залежать від предметної області, жанру і обсягу авторської роботи.

Об’єктом дослідження $є$ фразові банки як відносно нове явище в лінгвістиці i, зокрема, в академічній англійській мові. Основними завданнями роботи були:

- охарактеризувати поняття «фразовий банк» та принципи його застосування;

- виявити критерії підбору та локалізацію відповідних фразеологічних одиниць при написанні чи редагуванні наукової статті/дисертації.

Методи та методики дослідження. Ця стаття репрезентує стислий огляд літератури, що передбачає студіювання стилю науково-технічної прози щодо пошуку шляхів застосування фразових банків із застосуванням методів індукції та дедукції.

У лінгвістиці розвиток прагматичних студій сприяв відходу від традиційних методів аналізу. Стало очевидним, що системне дослідження мовних одиниць та мовлення неможливе без звернення до конкретних найуживаніших варіантів, які реалізуються у процесі текстової комунікації. До останніх належать передусім комунікативна, включаючи повідомлення і його вплив, прагматична й аксіологічні функції залежно від характеру впливу $[1 ; 5]$.

В цілому, у світовій літературі переважає уявлення про науковий текст як монотип, диференційований лише в плані відокремлення основних жанрів: наукова стаття, тези, оглядова стаття, монографія, дисертація тощо [1]. Академічний текст, зокрема текст наукової статті, розуміють як завершений словесний твір, котрий трактують як семіотичний об'єкт через висунення на перший план саме комунікативної функції $[1 ; 3 ; 6]$. В той же час саме жанр наукової статті (у якому дотримують структури IMRAD) відповідає критеріям валідної публікації на відміну від інших жанрів академічного письма [3].

Результати та дискусії. Банк академічних фраз розуміють як загальний ресурс для науково-педагогічних працівників усіх спеціальностей. Він має на меті надання готових одиниць академічного письма, які є характерними для вживання в основних розділах наукової статті/ дисертації: Анотація, Вступ (Огляд літератури), Матеріали і методи, Результати, Обговорення результатів дослідження і Висновки [3]. Можливі варіації залежно від предметної галузі, як у даному виданні. Найчастіше опускають Матеріали й Методи та об'єднують Результати й Обговорення (Дискусії). Особливо доцільним є використання банків фраз при написанні Вступу чи Огляду літератури $[4 ; 7 ; 8]$. Також корисним видається їх застосування при написанні рецензій на будь-які академічні роботи.

Банк академічних фраз спершу призначався для користувачів, для яких англійська мова не є рідною. Проте носії мови дедалі частіше звертаються до цього ресурсу, особливо ті науковці, що працюють у сфері емпіричних досліджень. Застосовуючи фразові банки, можна певні слова даного контексту заміняти іншими, наприклад:

$X$ is a major computer technology (public health) problem and the cause of... $-X-$ uе одна 3 основних проблем укомп'ютерній технологї (охороні здоров'я), щзо спричиняє ....[4]

Під час аналізу фразових банків, докладно відслідковують їхню подальшу структуризацію. Наприклад, у розділі Вступ можна виділити такі підрозділи, як General references to previous research (Загальні посилання на попередні дослідження) i Time-frame reference (Посилання на дослідження в межах певного часу), а в розділі Результати - Highlighting of similar findings (Виділення схожості результатів) і Highlighting of contradict findings (Виділення суперечливості результатів) [4].

Укладачі фразових банків звертають увагу на низку відмінних рис, що $є$ характерними для стилю науково-технічних документів. Перш за все це достовірність: автори інформують читача про відомі факти і про виконану раніше роботу, підкреслюючи наявність певних суперечок у літературі і необхідність подальших досліджень, враховуючи актуальність теми. Наведемо приклади [4]: 
In recent years, there has been an increasing amount of literature on... - За останні роки з'являсться все більше літератури, присвяченої..

A large and growing body of literature has investigated this issue. - Дослідженню даної проблеми присвячений великий масив літератури, кількість якої постійно зростає.

In the past two decades, several studies have focused on X. - 3a останні 20 років увага декількох дослідників була зосереджена на X.

Від авторів наукових робіт очікують критичного ставлення до використовуваних джерел літератури. Посилання на зовнішні джерела інформації $\epsilon$ обов'язковим, але саме автору належить право погоджуватися чи не погоджуватися з поглядами інших науковців - авторів усіх раніше опублікованих робіт - стосовно окремих аспектів дослідження. Фактично йдеться про пошук причин, через які чиїсь твердження або висновки не можуть сприйматися як безперечна істина, що призводить до виявлення проблем з аргументами/ методологією автора й пошуку критики його робіт з боку інших науковців [4]. Безперечно, своє критичне ставлення до літератури слід висловлювати в дуже обережній дипломатичній манері, а краще покладатися на усталені фрази типу:

The above findings contradict the study by Author [1]. S/he examined... - Наведені вище результати суперечать роботі автора [1], у якій було проаналізовано...

A study by Author suggests there should be... - У роботі ияього автора висловлюється припущення про існування...

Despite prior evidence [2] Author was keeping on his point of view ... - Незважаючи на отримані раніше факти [2], автор дотримується власної точки зору.

Форму посилань на літературу, а також форму написання окремих розділів статті/ дисертації можуть серйозно варіювати [7; 8]. Так, стиль «автор як суб'єкт» $є$ популярним у гуманітарній літературі і менш поширеним у природничих і точних науках. Наведемо приклади:

Author traces the development of ... - Автор відслідковує розвиток...

Author provides in-depth analysis of the work of... - Автор дає поглиблений аналіз роботи....

Author mentions the significant relationship between... - Автор окреслює те, щзо існує виражена залежність між...

Взагалі обережність формулювань, тобто відсутність категоричності навіть у висновках, $\epsilon$ характерною рисою стилю науково-технічних документів, наприклад [4]:

Неправильно: Drinking a lot of coffee causes nervousness in middle-aged people.

Правильно: Some studies suggest that drinking a lot of coffee is increasing the risk of nervousness in middle-aged people.

Наступною характерною рисою даного стилю є безособовість. Особові займенники вживаються тут досить рідко, особливо «я» (його майже завжди замінюють словом «ми»). Аудиторію цікавить не хто виконав ту чи іншу дію, а чому їі зробили, як і $з$ якою метою. Тому типовим для академічних текстів $\epsilon$ вживання пасивного стану задля пом'якшення зайвої категоричності тверджень.

Це суперечить думці багатьох лінгвістів про те, що загальним принципом підвищення чіткості та зрозумілості повідомлення залишається переважно використання активного стану дієслова [5; 6]. Стиль науково-технічних документів у цьому плані можна вважати винятком. Наведемо приклад:

Неправильно: You could say that Churchill made some catastrophic decisions early in the War.

Правильно: It can be said that Churchill made some catastrophic decisions early in the War.

Інші приклади з банку фраз [4] такі:

A survey of literature on ... is scarcely reported. - Огляд літератури щооо ...nредставлений досить слабо.

There have been relatively few recent studies on ... - Існує відносно мало сучасних робіт з...

Дослідження психології читачів вказують на наявність у останніх двох ідентифікаторів підвищеної уваги на початку речення і ближче до його кінця [5]. Тому, як правило, тему розкривають з початку речення/ абзацу, а нову, складнішу для сприйняття інформацію 
залишають на його кінець. Провідні методисти рекомендують ставити ключове слово (фразу) на початок речення чи абзацу [5; 6]:

Maintaining a healthy lifestyle requires eating a nutritious diet and getting regular exercise. [головне речення] A nutritious diet includes eating a variety of goods from each of the four food groups: meat, dairy, fruits and vegetables, and grains. Regular exercise is also an essential part of keeping a healthy lifestyle [допоміжні речення].

Викладений вище принцип побудови абзацу враховується при рецензуванні й оцінюванні всіх академічних робіт. 3 цієї причини укладачі фразових банків нерідко замінюють ключові слова літерою X:

$X$ is the leading cause of death in less-developed countries. - X залишається головною причиною смертності у країнах, щзо розвиваються.

$X$ has been studied extensively over the latest few decades because... - Протягом останніх десятиріч $X$ залишається предметом численних досліджень у зв'язку з...

Взагалі стилісти академічної прози приділяють велику увагу організаційній структурі письмової роботи, тобто правильному поділу іï на абзаци, зазначаючи, що нерідко їх бракує в академічних текстах [6].

Висновки. Таким чином, в пошуках оптимізації й універсалізації академічного письма зарубіжні вчені дійшли до такої інновації, як «фразовий банк». Наведені в нашій статті міркування свідчать про таке:

- стиль науково-технічної прози характеризується строгістю, когерентністю, обережністю висловів і використанням переважно пасивного стану дієслів;

- банки академічних фраз дозволяють економити час і зусилля науковців і освітян у написанні наукових статей і дисертацій, а також скоротити час магістрантів та аспірантів на вивчення академічної англійської мови;

- укладачі банків фраз дотримуються певних механізмів і критеріїв добору лексики, що виключає звинувачення їх користувачів у плагіаті.

Ми вбачаємо перспективи подальших досліджень у деталізації вживання фразових банків за конкретними розділами наукової статті/ дипломної роботи/ дисертації.

\section{References}

1. Bogatyrev, Andrew and Anna Tikhomirova. 2015. "Alternative stylistics of scientific text in the context of formation of inter-cultural academic text competence". World of Linguistics \& Communication, 5 (jubilee): URL: http://tverlingua.ru/ archive/042/08_42.pdf [in Russian].

2. Davis, Michael \&Morley, John. 2018. “Writing with sources: how much can be copied?' Student Plagiarism in Higher Education. Oxford: Routledge.

3. Diukanova, Nina and Luidmyla Nykonorova. 2011. "Stylistic specificity of English scientific paper writing". Scientific Bulletin of Lesi Ukrainki Volyn National University. Philological sciences series 4:186-190.

4. Morley, John. 2018. The Academic Phrasebank: an academic writing resource for students and researchers. http://www.phrasebank.manchester.ac.uk/index.htm

5. Naer, Vladimir. 1984. "Pragmatics of scientific texts. (verbal and non-verbal aspects". Functional Styles: LinguoMethodical Aspects. Moscow: Nauka.

6. Oleksandrova, Galina and Nina Diukanova. 2016."Fundamentals of English scientific and technical prose editing". Intellectual Archive 6: 91-98.

7. Swales, John. 1981. Aspects of article introductions. (Aston ESP Research Report No. 1). Birmingham: Language Studies Unit; University of Aston.

8. Swales, John. 1990. Genre analysis: English in academic and research settings. Cambridge: Cambridge University Press.

Семенов Юрий, Дюканова Нина. Применение банков фраз в английских академических текстах. Цель данной статьи - охарактеризовать такую инновацию, как банк фраз, и возможности его использования при написании и/ или редактировании английской академической прозы. В частности, рассматриваются научные статьи и диссертации. Концепция «банк академических фраз» основана на подходе к анализу академических текстов, впервые предложенному выдающимся британским лингвистом Джоном Свейлсом (John Swales) в 1980 гг. Он впервые выявил некоторые риторические клише, а также «шаг» - часть текста, выполняющую конкретную коммуникативную функцию. Джон Свейлс стремился продемонстрировать специфику языка, употребляемого при этом. «Шаг» как часть риторического анализа составляет в настоящее время основной элемент банка академических фраз. Общепризнано, что современный академический язык включает в себя значительный пласт фразеологии. Банк 
академических фраз представляет собой общий ресурс для научно-педагогических кадров. Его цель - предоставить фразеологические компоненты, организованные по принципу основных разделов научной статьи/диссертации. Использование банков фраз помогает правильно организовать академическую работу и позволяет вставить готовые фразы туда, где это представляется целесообразным. В данной статье исследуются стилистика и фразеология научно-технической прозы относительно классических разделов научной статьи/ диссертации, таких как Аннотация, Введение, Материалы и методы, Результаты, Обсуждение результатов работы и Выводы. Анализируются критерии подбора фраз, пригодных к использованию в банках фраз. Упоминаются вопросы плагиата при написании академических работ. На конкретных примерах рассматриваются особенности стиля научно-технических документов, нашедшие свое отображение в банках фраз. Даются универсальные рекомендации по использованию банков академических фраз независимо от предметной области, жанра и объема работы.

Ключевые слова: банк фраз, жанры научной статьи и диссертации, достоверность информации, критический анализ литературы, осторожность формулировок, безличность.

Semenov Yuriy, Diukanova Nina. Using of Phrasebanks in English Academic Texts. This work aims to present such an innovation as the 'Academic Phrasebank' and the possibilities of its application while writing and/ or editing English academic prose, in particular research articles (RA) and dissertations. The concept 'The Academic Phrasebank' is based on the approach to analysing academic texts pioneered by the outstanding British linguist John Swales in the 1980s. He identified some rhetorical patterns and defined a 'move' as a part of a text serving a specific communicative function. John Swales was also interested in showing the specificity of the language used to achieve the communicative purpose of a move. The move as a unit of rhetorical analysis is now applied as one of the key organising sub-categories of the Academic Phrasebank. It is generally recognised that there is a significant phraseological dimension in the up-to-date academic language. The Academic Phrasebank is an overall resource for academic and scientific writers. It provides the phraseological components organised according to the main sections of a research article or dissertation. It helps to organise of one's own writing, or the phrases can be incorporated in a text to the point. In this article, the issues of style and phraseology of scientific prose according to the classical sections of a research article or a dissertation have been studied. These sections are normally summarised as follows: Abstract, Introduction, Materials and Methods, Results, Discussion, and Conclusions. The criteria of the phrases applicable for including into banks have been analysed. The specificity of the style of academic writing reflected in a Phrasebank has been exemplified in detail. The problem of avoiding plagiarism in academic texts has been mentioned. The universal recommendations with regard of the 'Academic Phrasebank' usage in academic writing apart from a subject area, a genre and a scope of a paper have been given.

Keywords: academic phrasebank, genres of research paper and dissertation, evidence-base, critical thinking, cautiousness, impersonality.

DOI: https://doi.org/10.32782/2410-0927-2020-12-29

УДК 811.111

Любов Сенчук, Ірина Волощук

\section{ПЕРЕКЛАДАЦЬКИЙ АСПЕКТ МЕТАФОРИЧНИХ І МЕТОНІМІЧНИХ ТРАНСФОРМАЦЙ У ТЕКСТАХ ЗАСОБІВ МАСОВОЇ ІНФОРМАЦЇ̈}

Аналітичні та художньо-публіцистичні тексти в уявленні традиційної друкованої журналістики $є$ характерними протилежностями, адже для створення першого жанру за основу журналістами беруться факти та суворий стиль побудови, а для другого є характерним використання великої кількості мовностилістичних засобів. Сучасний розвиток мови та ЗМІ дозволив відійти від цих традицій, тож наразі в аналітичних матеріалах починають 3'являтись різні лінгвостилістичні засоби на рівні з художньо-публіцистичними.

У статті ретельно розглянуті сучасні тенденції у використанні метафор і метонімій та їх практичне вживання журналістами під час створення медійного тексту аналітичного чи художньо-публіцистичного жанру, зокрема використання палітри мовностилістичних засобів, що забезпечує досягнення необхідної емотивності та експресивності в реалізації прагматичних стратегій. Дослідники, які займались вивченням стилістичних троп і фігур, наголошують, що для сучасних засобів масової інформації характерне використання всієї їх палітри. Отже, їх роль у тексті дуже суттєва, адже стилістичні засоби посилюють вплив, що здійснюється на читача, а також спрощують розуміння написаного, викликаючи певні асоціації. Вживання метафор і метонімій є продуктивною частиною творення образності та емотивності в сучасних медійних текстах.

Метою роботи є дослідження перекладацького аспекту метафоричних і метонімічних трансформацій у контексті сучасної мови медіа, адже через стрімкий розвиток мови ЗМІ та зацікавленість читачів у світових новинах все частіше можна побачити їх переклади в українських виданнях.

Сучасні засоби масової інформації є рушієм мовної системи. Під час використання метафоричних i метонімічних сполук у медіа відбуваються процеси їх творення та адаптації у мову. Часто журналісти беруть не

(C) Сенчук Л., Волошук I., 2020 